\title{
Effect of Different Sterilization Treatments on Micropropagation of Potato cv. Kufri Lima
}

\author{
Bichhinna Maitri Rout ${ }^{1}$, A. K. Bhatia ${ }^{1}$, Subhash Kajla ${ }^{2 *}$, \\ Anil K. Poonia ${ }^{2}$ and Praveen Batra ${ }^{2}$ \\ ${ }^{1}$ Department of Vegetable Science, CCSHAU, Hisar, Haryana-125004, India \\ ${ }^{2}$ Centre for Plant Biotechnology, CCSHAU Campus, Hisar, Haryana-125004, India \\ *Corresponding author
}

\section{A B S T R A C T}

Keywords

kufri lima, sterilization, in vitro, survival

Article Info

Accepted:

12 February 2020

Available Online:

10 March 2020
The present experiment was conducted to standardize an efficient protocol for rapid multiplication of an important cultivar Kufri Lima. The findings showed that the surface sterilization with $0.2 \%$ Bavistin $+0.4 \%$ streptocyclin for 45 minutes followed by $0.1 \% \mathrm{HgCl}_{2}$ treatment for 55 seconds was optimum for in vitro culture establishment and maximum survival percentage.

\section{Introduction}

Potato (Solanum tuberosum L.) also eulogized as white or Irish potato, is considered to be one of the most valuable cool-season tuber crop which is grown worldwide. Globally, it is the fourth most important food crop for human consumption after wheat, rice and maize (Levy et al., 2013). It is often used as a substitute for cereals because of its higher availability of carbohydrate.

It is one of the principal cash crops of India as it produces higher yield than other cereal crops. According to Chanakya et al., (2015), the production of potato is more in terms of protein and calories per unit area as well as per unit time and per unit of water in comparison to other major plant food. Potato is a sensitive crop for many viruses; many of them are transmitted mechanically except few like PLRV (Mike Mayo et al., 2000).

It can be reduced by propagation of stem cutting, by heat treatment and by apical meristem culture (Samant et al., 2018). Aseptically, all culture vessels, media and instruments used in handling tissues, as well as explant itself must be sterilized to keep the air, surface and floor free of dust in tissue 
culture technique. Surface sterilization is the most crucial step before the inoculation of explants. Various sterilization agents like $\mathrm{HgCl}_{2}(0.1 \%), \mathrm{NaOCl}$ (5.25\% v/v approx.), $\mathrm{CaOCl}_{2}\left(0.8 \%\right.$ v/v), $70 \%$ ethanol, $\mathrm{H}_{2} \mathrm{O}_{2}$ (3$10 \% \mathrm{v} / \mathrm{v})$ etc. can be used in plant tissue culture. Pollock et al., (1983) stated that antimicrobial agents should not react with medium components and remain unaffected by $\mathrm{pH}$ so the use of water soluble and stable is optimal for micropropagation.

Dhingra et al., (1992) explained that surface sterilization should be done before transferring explants into the nutrient medium as its surface carries a wide range of microbial contaminants. Bacteria and fungi are the principal microbial contaminants which are frequently noticed in in vitro cultures (Cassells, 1990; Reed et al., 1995; Pereira et al., 2003). Chawla (2003) stated that all operations should be accomplished in laminar air flow sterile cabinet. Kane (2003) has explained that mortality, tissue necrosis or variable growth of cultured plantlets is due to fast establishment of microbes in the cultures which rapidly multiplies leading to depletion of nutrients in the medium and produce toxic substances within the medium as a result partial or total loss of culture occurs. Danso et al., (2011) revealed that when stronger and systemic sterilants are used the elimination of endophytic microbes through surface sterilization found to be effective to some extent.

\section{Materials and Methods}

Shoot tip explants $(2-3 \mathrm{~cm})$ of the cultivar Kufri Lima were taken from the research field of Department of Vegetable Science and Centre for Plant Biotechnology and were washed with mild liquid detergent for 10 minutes followed by washing under running tap water. The explants were surface sterilized with $0.2 \%$ bavistin $+0.2 \%$ streptocyclin or
$0.2 \%$ bavistin $+0.4 \%$ streptocyclin for 45 minutes followed by washing with double distilled water for 4-5 times (Mohapatra et al., 2016). In laminar air flow chamber the explants of both the cultivars were surface sterilized with $0.1 \% \quad \mathrm{HgCl}_{2}$ for different durations (35-65 seconds) and thoroughly rinsed with sterilized double distilled water for 5-6 times to remove the traces of $\mathrm{HgCl}_{2}$.

\section{Results and Discussion}

Among the various surface sterilization treatments used, the highest survival percentage $(100 \%)$ was observed when shoot tip explants were given same sterilization treatment (as above) $\mathrm{ST}_{7}(0.2 \%$ bavistin + $0.4 \%$ streptocyclin for 45 minutes $+0.1 \%$ $\mathrm{HgCl}_{2}$ for 55 seconds). Furthermore, good surface sterilization $(73 \%)$ was recorded when $\left(\mathrm{ST}_{6}\right)$ treatment $(0.2 \%$ Bavistin and $0.4 \%$ streptocyclin for 45 minutes $+0.1 \% \mathrm{HgCl}_{2}$ for 45 seconds) given to shoot tip explants. When the shoot tip explants were given $\left(\mathrm{ST}_{1}\right)$ treatment $(0.2 \%$ Bavistin and $0.2 \%$ streptocyclin for 45 minutes $+0.1 \% \mathrm{HgCl}_{2}$ for 35 seconds) the least survival percentage (26\%) was recorded. The increase in time of $\mathrm{HgCl}_{2}$ beyond 55 seconds resulted in reduction of survival percentage.

The present study affirmed that the explants were not properly sterilized when $\mathrm{HgCl}_{2}$ was used alone at lower concentration. The survival percentage of explants was reduced when the time of $\mathrm{HgCl}_{2}$ was increased beyond 55 seconds. Likewise Gami et al., (2013) taken excised explants and treated with $0.1 \%$ $\mathrm{HgCl}_{2}$ (Mercuric chloride) for 30 seconds and surface sterilized by washing with sterile distilled water in subject to potato cv. Esprit, Lady Rosseta and Meridian. The survival of nodal segments was found to be highest when $0.2 \% \mathrm{HgCl}_{2}$ solution for 60 seconds was used for surface sterilization (El Dessoky et al., 2016). 
Table.1 Effect of different sterilization treatments of explants (shoot tips) in cv. Kufri Lima

\begin{tabular}{|c|c|c|c|c|c|c|}
\hline \multirow{2}{*}{$\begin{array}{l}\text { Sr. } \\
\text { No. }\end{array}$} & \multirow{2}{*}{$\begin{array}{l}\text { Code } \\
\text { ST* }\end{array}$} & \multicolumn{3}{|c|}{ Sterilization treatments } & \multicolumn{2}{|c|}{ Shoot tips (Explants) } \\
\hline & & $\begin{array}{l}\mathrm{HgCl}_{2} \\
(0.1 \%) \\
\text { in sec }\end{array}$ & $\begin{array}{l}\text { Bavistin } \\
(0.2 \%)+ \\
\text { Streptocyclin } \\
(0.2 \%) \text { min }\end{array}$ & $\begin{array}{l}\text { Bavistin } \\
(0.2 \%)+ \\
\text { Streptocyclin } \\
(0.4 \%) \text { min }\end{array}$ & $\begin{array}{l}\text { Survival } \\
\text { percentage }\end{array}$ & $\begin{array}{l}\text { Contamination } \\
\text { percentage }\end{array}$ \\
\hline 1 & $\mathrm{ST}_{0}$ & 0.0 & 0.0 & 0.0 & 0.0 & 100.0 \\
\hline 2 & $\mathrm{ST}_{1}$ & 35 & 45 & - & 26.0 & 74.0 \\
\hline 3 & $\mathrm{ST}_{2}$ & 45 & 45 & - & 47.0 & $\mathbf{5 3 . 0}$ \\
\hline 4 & $\mathrm{ST}_{3}$ & 55 & 45 & - & 66.0 & 34.0 \\
\hline 5 & $\mathrm{ST}_{4}$ & 65 & 45 & - & 62.0 & 23.0 \\
\hline 6 & $\mathrm{ST}_{5}$ & 35 & - & 45 & 42.0 & 58.0 \\
\hline 7 & $\mathrm{ST}_{6}$ & 45 & - & 45 & 73.0 & 27.0 \\
\hline 8 & $\mathrm{ST}_{7}$ & 55 & - & 45 & 100.0 & 0.0 \\
\hline 9 & $\mathbf{S T}_{8}$ & 65 & - & 45 & 69.0 & 0.0 \\
\hline
\end{tabular}

*ST-sterilization treatment
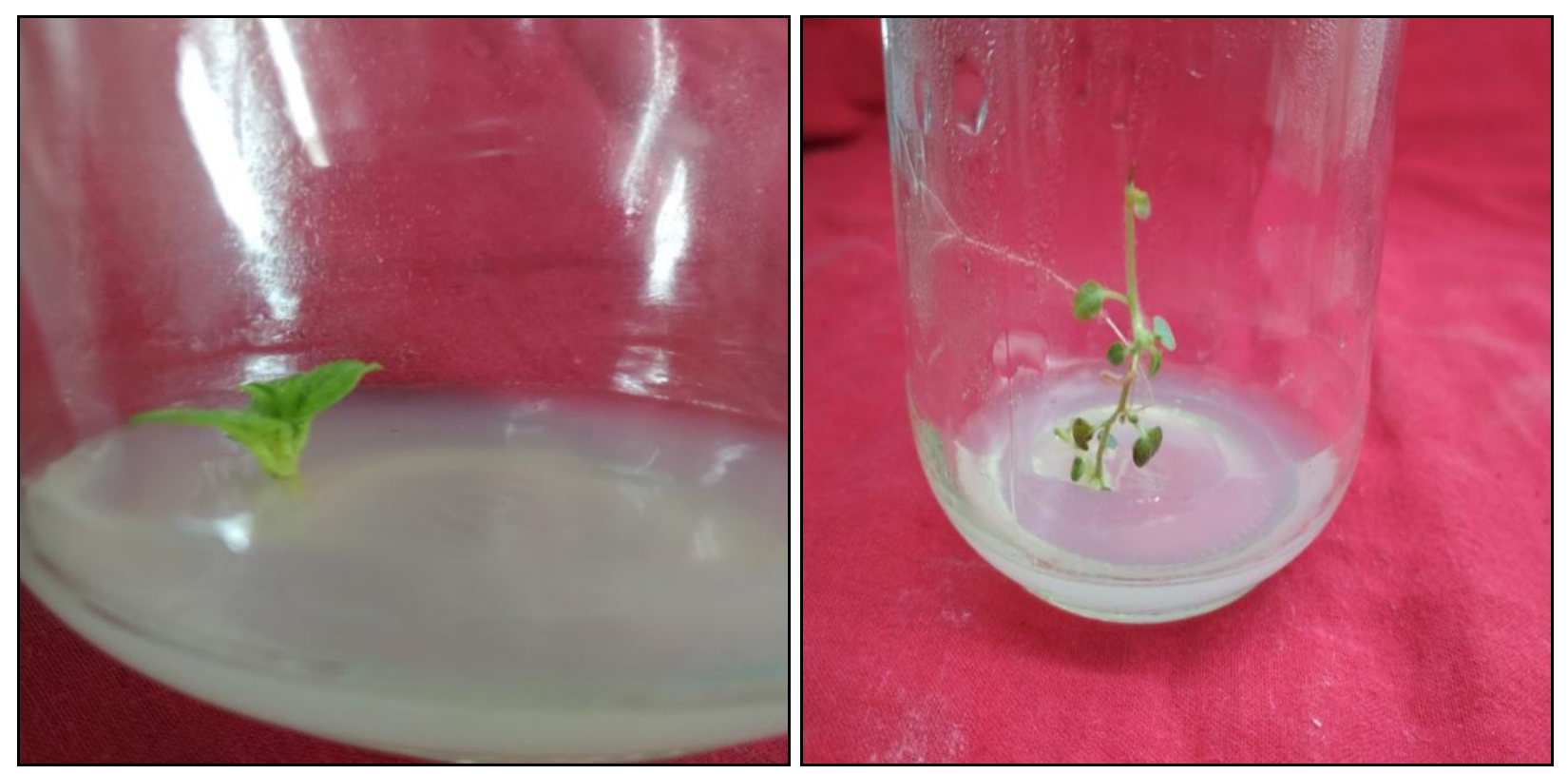

Fig.1 
Mohapatra et al., (2016) illustrated that when the explants (shoot tips) were surface sterilized with $0.2 \%$ bavistin \& $0.4 \%$ streptocyclin (45 minutes) and $0.1 \%$ mercuric chloride (60 seconds) the maximum survival percentage $(100 \%)$ was observed.

The present experiment was undertaken with a view to optimize the sterilization conditions considering for micropropagation in Kufri Lima and can be proceeded for further steps by using various growth regulators in media for large scale production of virus free plantlets.

\section{References}

Cassells, A. C. (1990). Problems in tissue culture, culture contamination. In: Micropropagation- Technology and Application. (Debergh, P. C. and Zimmerman R. H., (eds.), Kluwer Academic Publishers, London, pp. 3145.

Chanakya, M.S., Maurya, K.A. and Hargobind, W.F. (2015). A study on the use of various PGR combinations for efficient in vitro regeneration of $\mathrm{cv}$. kufri jyoti in kumaun hills, India. African Journal of Crop Science, 3(5): 176-182.

Chawla, H. S. (2003). Plant Biotechnology: Laboratory manual for plant biotechnology, Oxford \& IBH Publishing Co. Pvt. Ltd. New Delhi.

Danso, K.E., Azu, E., Elegba, W., Asumeng, A., Amoatey, H. M. and Klu, G.Y.P. (2011). Effective decontamination and subsequent plantlet regeneration of sugarcane (Sacchrum officinarum L.) in vitro. International Journal of Integrative Biology, 11(2): 90-96.

Dhingra, M.K., Naik, P.S., Chandra, R. and Randhawa, G.J. (1992). Tissue culture technique for potato health, conservation, micropropagation and improvement. Technical Bulletin, 39.

El Dessoky, S., Attia, A.O., Ismail, I.A. and El-Hallous, E.I. (2016). In vitro Propagation of Potato under Different Hormonal Combinations. International Journal, 4(1): 684-689.

Gami, R. A., Parmar, S. K., Patel, P. T., Tank, C. J., Chauhan, R. M., Bhadauria, H.S. and Solanki, S.D. (2013). Microtuberization, minitubers formation and in vitro shoot regeneration from bud sprout of potato (Solanum tuberosum L.) cultivar K. badshah. African Journal of Biotechnology, 12(38):5640-5647.

Kane, M. (2003). Bacterial and fungal indexing of tissue cultures. Journal of Allergy and Immunology, 94: 393-400.

Levy, D., Coleman, W. and Veilleux, R. (2013). Adaptation of potato to water shortage irrigation management and enhancement of tolerance to drought and salinity. American Journal of Potato Reearch, 90: 186-206.

Mayo, M., Ryabov, E., Fraser, G., \& Taliansky, M. (2000). Mechanical transmission of Potato leafroll virus. Journal of General Virology, 81(11): 2791-2795.

Mohapatra, P. P., Batra, V. K., Kajla, S., Poonia, A. K., and Kumar, N. M. (2016). Effect of different growth regulators on in vitro micro-propagation of Kufri Frysona. Journal of Applied and Natural Science, 8(2): 535-540.

Pollock, K., Barfield, D. G. and Shields, R. (1983). The toxicity of antibiotics to plant cell cultures. Plant cell reports, 2(1): 36-39.

Samant A., Kumar V.A., Kumar A., Shukla P.S. and Joshi K. (2018). In-vitro microtuber production in potato cultivar kufri himalini. Advances in Plants \& Agriculture Research, 8(6):648-653. 


\section{How to cite this article:}

Bichhinna Maitri Rout, A. K. Bhatia, Subhash Kajla, Anil K. Poonia and Praveen Batra. 2020. Effect of Different Sterilization Treatments on Micropropagation of Potato cv. Kufri Lima. Int.J.Curr.Microbiol.App.Sci. 9(03): 1605-1609. doi: https://doi.org/10.20546/ijcmas.2020.903.188 